Journal Club

Editor's Note: These short, critical reviews of recent papers in the Journal, written exclusively by graduate students or postdoctoral fellows, are intended to summarize the important findings of the paper and provide additional insight and commentary. For more information on the format and purpose of the Journal Club, please see http://www.jneurosci.org/misc/ifa_features.shtml.

\title{
The Role of $\beta$-Amyloid in Alzheimer's Disease-Related Neurodegeneration
}

\author{
Mitchell R. Goldsworthy and Ann-Maree Vallence \\ The Robinson Institute, School of Paediatrics and Reproductive Health, University of Adelaide, Adelaide 5005, Australia \\ Review of Wirth et al.
}

It is currently estimated that over 35 million people worldwide have dementia, and with demographic trends of an aging global population this figure is expected to triple by 2050 (Prince and Jackson, 2009). As the leading cause of dementia, Alzheimer's disease (AD) is the source of much emotional and financial strain. Although there has been considerable research aimed at developing diseasemodifying therapies that target different features of $\mathrm{AD}$ pathology, debate continues over which pathological features are central to disease progression.

A key pathological feature of $\mathrm{AD}$ is the formation of neuritic plaques composed of extracellular deposits of $\beta$-amyloid $(\mathrm{A} \beta)$ peptides. The temporal profile of pathological features together with genetic risk factors for $\mathrm{AD}$ have led to the hypothesis that accumulation of $\mathrm{A} \beta$ oligomers during early, preclinical stages of the disease initiates a cascade of events resulting in synaptic dysfunction, neural loss and atrophy within temporoparietal and hippocampal regions, and this neurodegeneration, in turn, causes cognitive decline (Jack et al., 2010). If this hypothesis is correct, biomarkers designed to detect $A \beta$ accumulation in preclinical

Received May 27, 2013; revised July 2, 2013; accepted July 5, 2013. We thank Assistant Professor M.C. Ridding for his valuable advice.

Correspondence should be addressed to Mitchell Goldsworthy, NeuroPAD DX 650-517, Robinson Institute, School of Paediatrics \& Reproductive Health, University of Adelaide, Adelaide, SA 5005, Australia. E-mail: mitchell.goldsworthy@adelaide.edu.au.

DOI:10.1523/JNEUROSCI.2252-13.2013

Copyright $\odot 2013$ the authors $\quad 0270-6474 / 13 / 3312910-02 \$ 15.00 / 0$ populations may have an important role in the early diagnosis of AD (Sperling et al., 2011).

One method for detecting $A \beta$ deposits is positron emission tomography (PET) imaging of plaques labeled with amyloidbinding radiotracers such as $\left[{ }^{11} \mathrm{C}\right]$ Pittsburgh compound B (PiB) (Klunk et al., 2004). Retention of $\mathrm{PiB}$ provides a good measure of fibrillar (insoluble) A $\beta$ load, but the relationship between $\mathrm{PiB}$ retention and $\mathrm{AD}$-related neurodegeneration and cognitive decline, and therefore its usefulness in identifying individuals with an increased risk of developing $\mathrm{AD}$, is poorly understood.

In a recent article published in The Journal of Neuroscience, Wirth et al. (2013) investigated the relationship between $\mathrm{A} \beta$ deposits and $\mathrm{AD}$-related neurodegeneration, as well as the association of these pathological features with cognitive functioning in cognitively normal older individuals. An age-adjusted, multimodal approach was used to quantify neural integrity and neurodegeneration in brain regions normally affected by $\mathrm{AD}$. This included a functional measure of glucose metabolism (an index of synaptic activity), as assessed by $\left[{ }^{18} \mathrm{~F}\right.$ ] fluorodeoxyglucose (FDG) PET, as well as structural measures of cortical thickness and hippocampal volume using magnetic resonance imaging (MRI). Using PiB PET to assess $\mathrm{A} \beta$ plaque load, Wirth and colleagues (2013) found no evidence of an association between $\mathrm{PiB}$ retention and neurodegeneration in cognitively normal older subjects. Additionally, neurodegeneration, but not $\mathrm{PiB}$ retention, was associated with poorer performance on tests of memory and executive function. These findings suggest that neurodegeneration occurs within $\mathrm{AD}$-affected brain regions independent of $\mathrm{A} \beta$ accumulation, and this neurodegeneration contributes more to cognitive performance than insoluble $\mathrm{A} \beta$ in cognitively normal older individuals. Although $\mathrm{A} \beta$ accumulation was a poor predictor of cognitive performance in older individuals, the relationship between neurodegeneration within $\mathrm{AD}$-affected brain regions and cognitive performance was stronger in individuals with high $\mathrm{PiB}$ retention, suggesting the negative impact of reduced neural integrity on cognitive function was enhanced in individuals with high $\mathrm{A} \beta$ plaque load.

The strong association between cognitive performance and neurodegeneration, but not $\mathrm{A} \beta$ deposits, is consistent with the $\mathrm{A} \beta$ cascade model of $\mathrm{AD}$ pathogenesis, which suggests that neural injury and neurodegeneration occurring downstream of $\mathrm{A} \beta$ accumulation correlate better with the severity of clinical symptoms than biomarkers of insoluble $\mathrm{A} \beta$, which reach a plateau at an earlier stage during disease progression (Jack et al., 2010). Also consistent with this model is the finding that older individuals with both $\mathrm{A} \beta$ deposits and neurodegeneration within $\mathrm{AD}$-affected brain regions performed worse on cognitive tests of memory and executive function than those without A $\beta$ deposits. However, Wirth et al. (2013) observed neurodegeneration within $\mathrm{AD}$ - 
affected brain regions in $\mathrm{A} \beta$-negative, as well as $\mathrm{A} \beta$-positive, older individuals, making it unlikely that $A \beta$ initiated neurodegeneration in these cases. This finding is consistent with a recent population-based, cross-sectional study by Jack et al. (2012), which classified approximately one quarter of their sample of cognitively normal older individuals as having abnormal neurodegenerative biomarkers (assessed using FDG PET and hippocampal volume) without the presence of $\mathrm{A} \beta$ accumulation. It was suggested that $\mathrm{A} \beta$-independent neurodegeneration in this group of subjects may have resulted from pathological processes associated with the preclinical stages of non-AD causes of dementia, such as vascular dementia or dementia with Lewy bodies. Similar factors may have led to neurodegeneration in the study by Wirth et al. (2013). Therefore, longitudinal assessments will be required to determine the validity of their multimodality neurodegenerative biomarker for detecting preclinical AD pathology.

The development of neurodegeneration independent of $\mathrm{A} \beta$ deposition in older individuals may point to other factors as being important during the preclinical stages of AD. For instance, in addition to $\mathrm{A} \beta$ plaque formation, $\mathrm{AD}$ is characterized by neurofibrillary tangles formed by intracellular deposits of hyperphosphorylated tau protein filaments. Indeed, there is evidence from autopsy studies that subcortical tauopathy may precede $\mathrm{A} \beta$ plaque formation (Braak and Del Tredici, 2011), prompting a revised version of the $\mathrm{A} \beta$ cascade model of $\mathrm{AD}$ pathogenesis to include tau and $A \beta$ accumulation as initially separate pathological processes arising independent of one another (Jack et al., 2013). However, another view is that tau hyperphosphorylation is stimulated by soluble A $\beta$ (De Felice et al., 2008).

Importantly, although $\mathrm{PiB}$ PET can provide a good indication of the fibrillar forms of $A \beta$ that make up neuritic plaques, it is unable to detect the soluble, oligomeric forms of $\mathrm{A} \beta$. There is a wealth of data demonstrating the neurotoxic and synaptotoxic properties of soluble A $\beta$ oligomers, suggesting that this form may be more relevant to neurodegeneration and the development of cognitive decline in AD (Walsh and Selkoe, 2007). However, unlike for fibrillar $A \beta$, well validated biomarkers for the in vivo detection of oligomeric $\mathrm{A} \beta$ species in humans is currently lacking. Although advances are being made toward developing approaches for the measurement of $A \beta$ oligomers in CSF (Fukumoto et al., 2010; Santos et al., 2012), more research is required to determine the role of these oligomeric species during the preclinical stages of $\mathrm{AD}$ progression.

A detailed understanding of the pathological processes underlying $\mathrm{AD}$ is critically important for the development of more effective early intervention. Wirth et al. (2013) found that although the relationships between $\mathrm{A} \beta$ deposits, neurodegeneration, and cognitive performance in older individuals were partially consistent with current theories regarding the central role of $\mathrm{A} \beta$ in $\mathrm{AD}$ progression, the presence of $\mathrm{AD}$-related neurodegeneration in the absence of $A \beta$ plaques in some individuals suggests that other features of AD pathology may also be important during the preclinical stages of the disease.

\section{References}

Braak H, Del Tredici K (2011) The pathological process underlying Alzheimer's disease in individuals under thirty. Acta neuropathologica 121:171-181. CrossRef Medline

De Felice FG, Wu D, Lambert MP, Fernandez SJ, Velasco PT, Lacor PN, Bigio EH, Jerecic J, Acton PJ, Shughrue PJ, Chen-Dodson E, Kinney GG, Klein WL (2008) Alzheimer's diseasetype neuronal tau hyperphosphorylation induced by a beta oligomers. Neurobiol Aging 29:1334-1347. CrossRef Medline

Fukumoto H, Tokuda T, Kasai T, Ishigami N, Hidaka H, Kondo M, Allsop D, Nakagawa M (2010) High-molecular-weight beta-amyloid oligomers are elevated in cerebrospinal fluid of Alzheimer patients. FASEB J 24:2716-2726. CrossRef Medline

Jack CR Jr, Knopman DS, Jagust WJ, Shaw LM, Aisen PS, Weiner MW, Petersen RC, Trojanowski JQ (2010) Hypothetical model of dynamic biomarkers of the Alzheimer's path- ological cascade. Lancet Neurol 9:119-128. CrossRef Medline

Jack CR Jr, Knopman DS, Weigand SD, Wiste HJ, Vemuri P, Lowe V, Kantarci K, Gunter JL, Senjem ML, Ivnik RJ, Roberts RO, Rocca WA, Boeve BF, Petersen RC (2012) An operational approach to National Institute on Aging-Alzheimer's Association criteria for preclinical Alzheimer disease. Ann Neurol 71:765-775. CrossRef Medline

Jack CR Jr, Knopman DS, Jagust WJ, Petersen RC, Weiner MW, Aisen PS, Shaw LM, Vemuri P, Wiste HJ, Weigand SD, Lesnick TG, Pankratz VS, Donohue MC, Trojanowski JQ (2013) Tracking pathophysiological processes in Alzheimer's disease: an updated hypothetical model of dynamic biomarkers. Lancet Neurol 12:207-216. CrossRef Medline

Klunk WE, Engler H, Nordberg A, Wang Y, Blomqvist G, Holt DP, Bergström M, Savitcheva I, Huang GF, Estrada S, Ausén B, Debnath ML, Barletta J, Price JC, Sandell J, Lopresti BJ, Wall A, Koivisto P, Antoni G, Mathis CA, Långström B (2004) Imaging brain amyloid in Alzheimer's disease with Pittsburgh compound-B. Ann Neurol 55:306-319. CrossRef Medline

Prince M, Jackson J, eds (2009) Alzheimer's disease international world alzheimer report 2009. London: Alzheimer's Disease International.

Santos AN, Ewers M, Minthon L, Simm A, Silber RE, Blennow K, Prvulovic D, Hansson O, Hampel H (2012) Amyloid-beta oligomers in cerebrospinal fluid are associated with cognitive decline in patients with Alzheimer's disease. J Alzheimers Dis 29:171-176. CrossRef Medline

Sperling RA, Aisen PS, Beckett LA, Bennett DA, Craft S, Fagan AM, Iwatsubo T, Jack CR Jr, Kaye J, Montine TJ, Park DC, Reiman EM, Rowe CC, Siemers E, Stern Y, Yaffe K, Carrillo MC, Thies B, Morrison-Bogorad M, Wagster MV, Phelps CH (2011) Toward defining the preclinical stages of Alzheimer's disease: recommendations from the National Institute on Aging-Alzheimer's Association workgroups on diagnostic guidelines for Alzheimer's disease. Alzheimers Dement 7:280-292. CrossRef Medline

Walsh DM, Selkoe DJ (2007) A beta oligomers-a decade of discovery. J Neurochem 101:1172-1184. CrossRef Medline

Wirth M, Madison CM, Rabinovici GD, Oh H, Landau SM, Jagust WJ (2013) Alzheimer's disease neurodegenerative biomarkers are associated with decreased cognitive function but not beta-amyloid in cognitively normal older individuals. J Neurosci 33:5553-5563. CrossRef Medline 